\title{
SULFUR DIOXIDE GAS ADSORPTION STUDY USING MIXED ACTIVATED CARBON FROM DIFFERENT BIOMASS
}

\author{
Nurul Syazlinie Abdul Shukor ${ }^{1}$, Azil Bahari Alias², Mohd Azlan Mohd Ishak ${ }^{3}$, Raja Razuan \\ Raja Deris $^{1}$, Ali H Jawad ${ }^{1}$, Khairul Adzfa Radzun ${ }^{1}$, Khudzir Ismail ${ }^{1 *}$ \\ ${ }^{1}$ Faculty of Applied Sciences, Universiti Teknologi MARA, 40450 Shah Alam, Selangor, Malaysia \\ ${ }^{2}$ Faculty of Chemical Engineering, Universiti Teknologi MARA, 40450 Shah Alam, Selangor, \\ Malaysia \\ ${ }^{3}$ Faculty of Applied Sciences, Universiti Teknologi MARA, Arau Campus, Perlis Branch, 02600 \\ Arau, Perlis, Malaysia
}

(Received: July 2018 / Revised: August 2018 / Accepted: October 2018)

\begin{abstract}
Activated carbon produced from coconut shell and rubber seed pericarp has a great potential to be used as gas adsorbent. Most researchers, however, focus on producing activated carbon from one single biomass. Another option is to produce activated carbon from blending two different types of biomass with the strategy to reduce dependency on one type of biomass and sustain the production of activated carbon. Further, the adsorption capacity of the activated carbon produced from different blended biomass would be increased in comparison to single biomass. Most activated carbon is produced via physical activation using the conventional pyrolysis heating system, which is very time-consuming. In this study, activated carbon from biomass, namely coconut shell (CS-AC), rubber seed pericarp (RSP-AC), and their blends (CSRSP-AC) were successfully produced by using $\mathrm{ZnCl}_{2}$ as the chemical activating agent. The activation process was performed in a modified commercial microwave oven at the irradiation power of $600 \mathrm{~W}$ for $20 \mathrm{~min}$. The single activated carbon and its blend were tested for their adsorption capacity for sulfur dioxide gas $\left(\mathrm{SO}_{2}\right)$ using evolved gas analyzer (EGA). The single RSP-AC and CS-AC samples produced breakthrough time for $\mathrm{SO}_{2}$ adsorption at $23 \mathrm{~min}$ and $14 \mathrm{~min}$, respectively. The longest $\mathrm{SO}_{2}$ breakthrough time for the blended activated carbon (CSRSP-AC) was achieved at 15 min with a ratio of 20:80 (CS:RSP) and was slightly longer than the individual CS-AC. The high amount of microporous RSP in the blend increases $\mathrm{SO}_{2}$ adsorption capacity. The presence of fly ash/Ca(OH) 2 catalyst in the blended CSRSP-AC (20:80) further improves $\mathrm{SO}_{2}$ adsorption capacity with the breakthrough time achieving at $36 \mathrm{~min}$ at the adsorption temperature of $35^{\circ} \mathrm{C}$. The SEM micrograph of blended CSRSP-AC with the addition of fly ash/Ca(OH) 2 catalyst after $\mathrm{SO}_{2}$ adsorption showed that the pores were clogged with some of the samples agglomerated and clustered, indicating that both activated carbon and fly $\operatorname{ash} / \mathrm{Ca}(\mathrm{OH})_{2}$ catalyst had interacted thoroughly with $\mathrm{SO}_{2}$ after the adsorption process.
\end{abstract}

Keywords: Activated carbon; Coconut shell; Gas adsorbent; Microwave; Rubber seed pericarp; Sulfur dioxide

\section{INTRODUCTION}

One of the emissions polluting the atmosphere is sulfur dioxide $\left(\mathrm{SO}_{2}\right)$, which is mainly released by industries threatening the environment and human health (Uçar et al.,

\footnotetext{
*Corresponding author's email: khudzir@salam.uitm.edu.my, Tel:+603-55444560, Fax: +603-55444562

Permalink/DOI: https://doi.org/10.14716/ijtech.v9i6.2358
} 
2009; Sumathi et al., 2010). The elimination of this gas from the stationary sources is important to prevent it from polluting the environment. Recently, many researchers have studied the removal of $\mathrm{SO}_{2}$ gas by using carbon-based materials (Bai et al., 2016; Sun et al., 2018; Shao et al., 2018).

In Malaysia, a high capacity of electricity is generated through the thermal power plants where the main source of fuel is supplied by burning coal. In recent years, about $2420 \mathrm{MW}$ of electricity has been generated from Sultan Salahuddin Abdul Aziz Shah power station, Kapar, Selangor by using more than a hundred tons of coal for the national usage (Amin et al., 2013). However, an increase in Malaysia's coal power plants leads to an increase in the formation of fly ash, which is a residue formed as a result of the combustion of bituminous coal (Ismail et al., 2007). This fly ash has a glassy, spherical shape with a very fine structure similar to that of cement. According to Wang and Wu (2006), the presence of fly ash has posed the industry the challenge of disposing and creating a more efficient recycling technique.

This work has studied the adsorption of $\mathrm{SO}_{2}$ on activated carbon, prepared from the coconut shell, rubber seed pericarp, and their blends. Activated carbon was prepared using the microwave irradiation technique. Previous researchers have reported the use of microwave heating in pyrolyzing the crude oil and other carbon materials (Leong et al., 2016; Yang \& Ani, 2016). This study provides comprehensive data about the cleaning of $\mathrm{SO}_{2}$ gas by using activated carbon from blending the coconut shell and rubber seed pericarp. The blended activated carbon was utilized in the presence of coal fly ash to improve the efficiency of $\mathrm{SO}_{2}$ adsorption. The coconut shell and rubber seed pericarp have successfully been converted into well-developed activated carbon with microporous characteristics and used to adsorb $\mathrm{SO}_{2}$ (Shukor et al., 2017). The effect of four important parameters have been investigated, and these include the blending ratio of activated carbon (CS:RSP), mass loading of sample in combustion cell, adsorption temperature, and addition of fly ash/Ca(OH) 2 toward $\mathrm{SO}_{2}$ adsorption. These parameters were chosen for investigation because of their significant influence on $\mathrm{SO}_{2}$ adsorption (Sumathi et al., 2010; Rubio \& Isquierdo, 2010). Further, the surface morphology of adsorbent before and after adsorption was also carried out to understand the effect between surface chemistry of adsorbents on the adsorption process.

\section{METHODS}

\subsection{Sample Preparation}

CS-AC, RSP-AC, and CSRSP-AC used in this study were prepared by chemical activation using $\mathrm{ZnCl}_{2}$ as the activating agent. The details of the preparation method have been reported elsewhere (Shukor et al., 2017). The weight sample $(10.00 \pm 0.01 \mathrm{~g})$ of the coconut shell, the rubber seed pericarp, and their blends (0:100, 20:80, 50:50, 80:20, and 100:0 (\%w/w)) were added to $50 \%$ of $\mathrm{ZnCl}_{2}$ solutions in a ratio of $1.5 \mathrm{~g} / \mathrm{g}$ sample at room temperature for $24 \mathrm{hr}$. The impregnated sample was heated using microwave irradiation at $600 \mathrm{~W}$ in the presence of nitrogen gas for $20 \mathrm{~min}$ (Idris et al., 2012). Then, the sample was washed with $0.1 \mathrm{M} \mathrm{HCI}$ and with cold distilled water to remove the organic matter residues until it was neutralized until $\mathrm{pH}$ 7. Finally, the sample was dried in an oven at $100^{\circ} \mathrm{C}$ overnight and ready for further analysis.

\subsection{Catalytic Sorbent Preparation}

The catalytic sorbent was prepared by using the impregnation method. The coal fly ash was mixed with $\mathrm{Ca}(\mathrm{OH})_{2}$ and activated carbon $(\mathrm{AC})$ in the presence of water in $1: 1: 1(\% \mathrm{w} / \mathrm{w})$ ratio. The entire slurry sample formed was stirred and heated to $90^{\circ} \mathrm{C}$ for $48 \mathrm{hr}$. The sample was cooled and kept in a glass desiccator for further analysis. 


\subsection{Sample Characterization}

The surface area of the sorbent was determined by $\mathrm{N}_{2}$ adsorption of Brunauer-Emmet-Teller (BET) using Model TM-3030Plus Tabletop Microscope. The BET surface area was measured by means of standard BET equation, applied with relative pressure $\left(\mathrm{P} / \mathrm{P}_{0}\right)$ ranging from 0.01 to 0.90 . The samples for the SEM analysis were prepared by cutting and placing the dried samples on a carbon tape to fit the specimen stub before being viewed.

\subsection{Activity Test}

The $\mathrm{SO}_{2}$ absorption activity test was performed using a fabricated fixed bed combustion cell (see Figure 1). The standard $\mathrm{SO}_{2}$ gas was measured and analyzed using an evolved gas analyzer (EGA) (Siemens Ultramat-23). About $1.0 \mathrm{~g}$ to $5.0 \mathrm{~g}$ of sample (i.e., single and blended activated adsorbent with and without fly ash $/ \mathrm{Ca}(\mathrm{OH})_{2}$ was dispersed on $0.05 \mathrm{~g}$ borosilicate glass wool located at the center of the combustion cell. Then, $\mathrm{SO}_{2}$ gas at the initial concentration of $1000 \mathrm{ppm}$ with $\mathrm{N}_{2}$ as balanced at the flow rate of $500 \mathrm{ml} \mathrm{min}^{-1}$ was passed through the sample at different temperatures ranging from $35^{\circ} \mathrm{C}$ to $200^{\circ} \mathrm{C}$. The concentration of $\mathrm{SO}_{2}$ gas before and after sorption process was measured and recorded continuously for every minute until it reached the breakthrough point $\left(\mathrm{C} / \mathrm{C}_{0}\right.$ versus time $)$. The amount of $\mathrm{SO}_{2}$ gas adsorbed by the sorbent was evaluated as adsorption breakthrough time of $\mathrm{SO}_{2}$ until both the inlet and outlet $\mathrm{SO}_{2}$ concentration became the same (Dahlan et al., 2008; Sumathi et al., 2010).

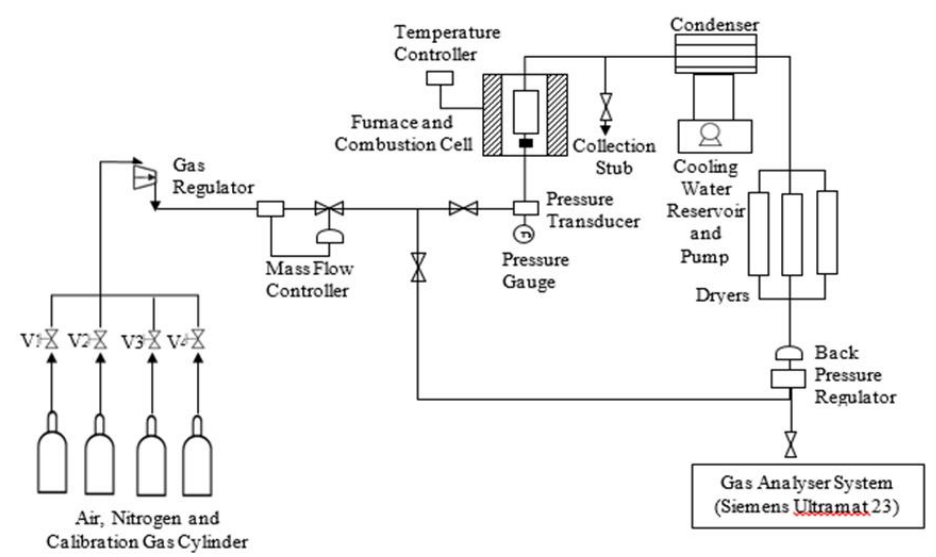

Figure 1 Schematic flow diagram of the evolved gas analysis experimental set-up for $\mathrm{SO}_{2}$ absorption activity test

\section{RESULTS AND DISCUSSION}

\subsection{Fly Ash Composition}

The results of XRF on the coal fly ash is shown in Table 1. The major composition of metal oxides present are $\mathrm{SiO}_{2}$, followed by $\mathrm{Al}_{2} \mathrm{O}_{3}, \mathrm{Fe}_{2} \mathrm{O}_{3}, \mathrm{TiO}_{2}, \mathrm{CaO}, \mathrm{K}_{2} \mathrm{O}, \mathrm{P}_{2} \mathrm{O}_{5}$, and $\mathrm{MgO}$ at the percentages of $59.4 \%, 21.6 \%, 9.19 \%, 3.22 \%, 2.78 \%, 1.51 \%, 0.86$, and $2.78 \%$, respectively. The other metal oxides and traces compound with minor composition of less than $1 \%$ are also presented in Table 1. According to Yao et al. (2015), coal fly ash could be used as support catalyst for various reactions, due to the higher stability of its principal component of metal oxides present in it. Fly ash that consists of higher content of oxides, such as iron oxides, poses a higher thermal stability, which can be utilized in heterogeneous catalyses. Moreover, Wang (2008) has reported that fly ash is effective to be used as catalyst for various reactions, such as solid, liquid, and gas phase oxidation. 
Table 1 The element composition of metal oxides present in fly ash

\begin{tabular}{lc}
\hline \multicolumn{1}{c}{ Element } & $\% \mathrm{MXO}_{\mathrm{Y}}$ \\
\hline $\mathrm{SiO}_{2}$ & 59.40 \\
$\mathrm{Al}_{2} \mathrm{O}_{3}$ & 21.60 \\
$\mathrm{Fe}_{2} \mathrm{O}_{3}$ & 9.19 \\
$\mathrm{TiO}_{2}$ & 3.22 \\
$\mathrm{CaO}$ & 2.78 \\
$\mathrm{~K} 2 \mathrm{O}$ & 1.51 \\
$\mathrm{P}_{2} \mathrm{O}_{5}$ & 0.86 \\
$\mathrm{MgO}$ & 0.30 \\
Traces Element & $<1$ \\
\hline
\end{tabular}

\section{2. $\mathrm{SO}_{2}$ Adsorption Activity Test}

The $\mathrm{SO}_{2}$ adsorption activity test is reported as the breakthrough time curve $\left(\mathrm{C} / \mathrm{C}_{\mathrm{o}}\right.$ versus $\left.\mathrm{t}\right)$, where $\mathrm{C}_{\mathrm{o}}$ is the initial concentration of $\mathrm{SO}_{2}$ (ppm) passing through the adsorbent, while $\mathrm{C}$ is the outlet concentration of $\mathrm{SO}_{2}(\mathrm{ppm})$ recorded from the gas analyzer. The effect of the activated biomass blending ratio was studied and the best adsorption breakthrough time of the blended sample was selected to further study its effect on other parameters, namely the amount of mass load in the combustion cell, the adsorption temperature, and the addition of catalytic fly ash/ $\mathrm{Ca}(\mathrm{OH})_{2}$ on the selected blended sample.

\subsubsection{Effect of activated biomass blending ratio on $\mathrm{SO}_{2}$ breakthrough time curve}

The effect of the blending ratio of activated biomass was investigated based on the breakthrough time curve. According to Sumathi et al. (2010), the sample is considered a good sorbent when it can maintain longer breakthrough time for $100 \%$ adsorption of $\mathrm{SO}_{2}$. Figure 2 shows the breakthrough time curve of the blended sample at different ratios of 100:0 (CS:RSP), 80:20 (CS:RSP), 50:50 (CS:RSP), 20:80 (CS:RSP), and 0:100 (CS:RSP), and the $\mathrm{SO}_{2}$ breakthrough times are portrayed in Table 2 .

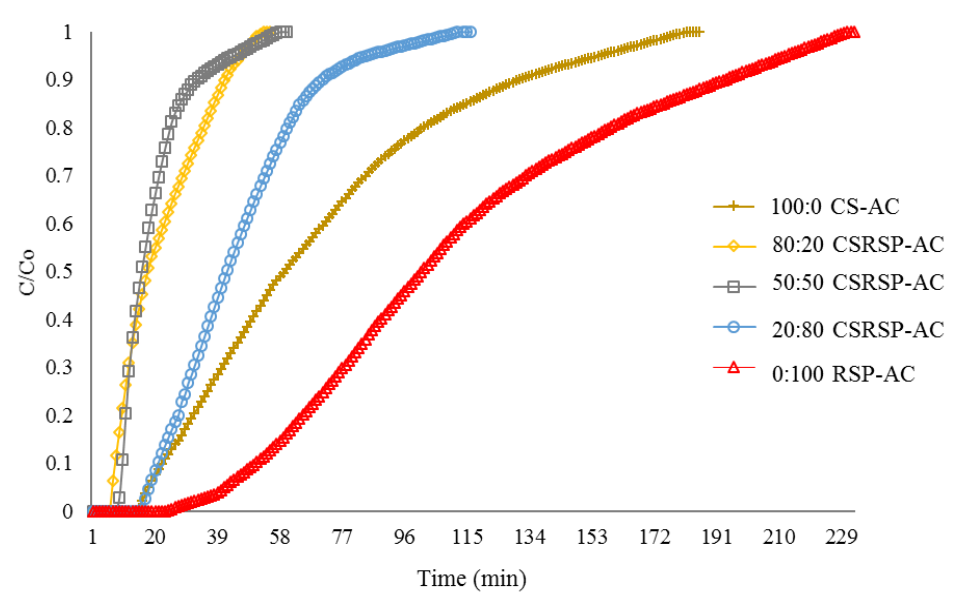

Figure $2 \mathrm{SO}_{2}$ adsorption breakthrough time curves for single (CS-AC and RSP-AC) and blended CSRSP-AC at $50 \%$ of $\mathrm{ZnCl}_{2}$ concentration with impregnation ratio of 1.5 at $35^{\circ} \mathrm{C}$

Table $2 \mathrm{SO}_{2}$ adsorption breakthrough time of $1.0 \mathrm{~g}$ single and different blended sample ratios

\begin{tabular}{cc}
\hline Blended sample (CS:RSP) & Adsorption breakthrough time (min) \\
\hline $100: 0$ & 14 \\
$80: 20$ & 6 \\
$50: 50$ & 8 \\
$20: 80$ & 15 \\
$0: 100$ & 23 \\
\hline
\end{tabular}


The results in Table 2 illustrate that single RSP-AC exhibits the longest adsorption breakthrough time of $23 \mathrm{~min}$ in comparison to the other blended sample at adsorption temperature of $35^{\circ} \mathrm{C}$. Similarly, the single CS-AC exhibits adsorption breakthrough time of 14 min. Apparently, the blended adsorbent with ratio of 20:80 (CS:RSP) exhibits the longest breakthrough time of $15 \mathrm{~min}$ in comparison to 80:20 (CS:RSP) and 50:50 (CS:RSP) at 6 min and $8 \mathrm{~min}$, respectively. This observation indicates that a high ratio of RSP over CS in the blend promotes a larger adsorption capacity for $\mathrm{SO}_{2}$. Liu and Adanur (2014) have reported that the higher micropore present in the adsorbent increases the capability of $\mathrm{SO}_{2}$ absorption because mesopores and macropores encourage the blockage of the surface adsorbent. In other words, the $\mathrm{SO}_{2}$ breakthrough time of adsorbent is directly dependent on the ratio of micropore present in the sample. The blended activated sample of 80:20 (CS:RSP), consisting of mainly mesopores, exhibits the lowest breakthrough time of $6 \mathrm{~min}$ due to the higher ratio of CS over RSP. This blended sample rapidly became saturated by $\mathrm{SO}_{2}$ after the breakthrough and produced a steeper slope in the curve. Similarly, the 50:50 (CS:RSP) blended sample also has a shorter breakthrough time with steeper slope, which reflects a lower adsorption capacity due to the poor development of porous structure (Izquierdo \& Rubio, 2008). Hence, the adsorbent with a blending ratio of (20:80) exhibits a higher adsorption capacity in comparison to the other blending ratio and was selected to observe the effect of other parameters affecting the $\mathrm{SO}_{2}$ adsorption breakthrough time.

3.2.2. Effect of adsorbent mass load in the combustion cell on $\mathrm{SO}_{2}$ breakthrough time curve

Figure 3 shows the effect of mass sample loading in the fixed bed combustion cell. The blended activated sample with a ratio of 20:80 (CS:RSP) ranging from $1.0 \mathrm{~g}$ to $5.0 \mathrm{~g}$ was analyzed for the $\mathrm{SO}_{2}$ adsorption capacity test. The $\mathrm{SO}_{2}$ adsorption breakthrough time at different mass loading of adsorbents are tabulated in Table 3.

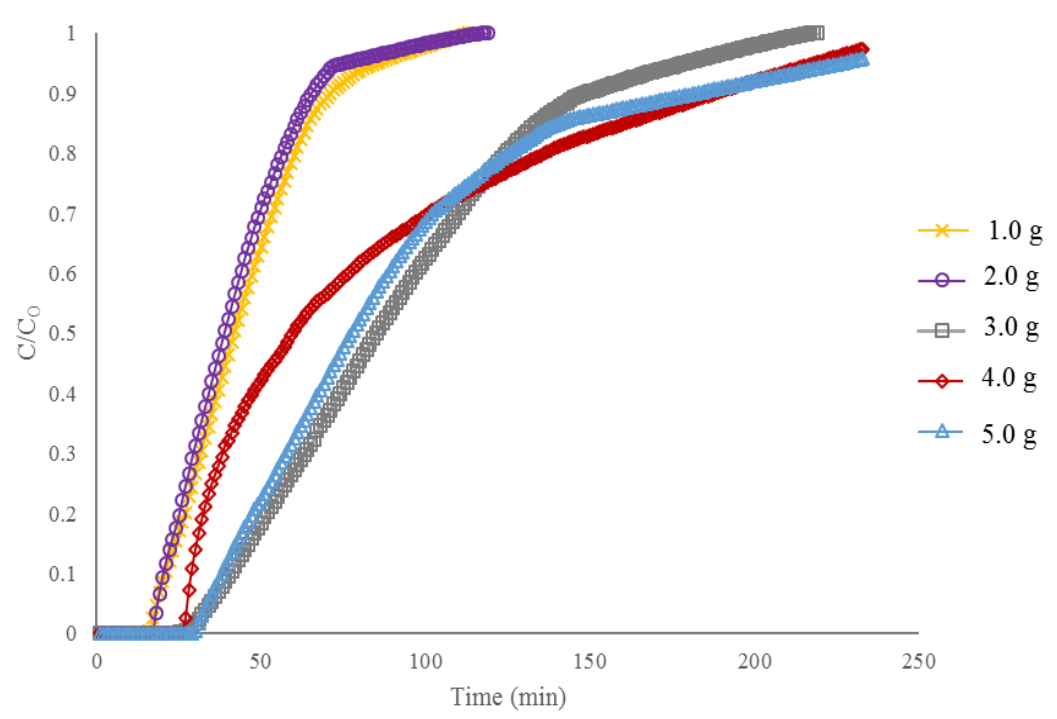

Figure $3 \mathrm{SO}_{2}$ adsorption breakthrough time curves for CSRSP-AC (20:80) at different mass loading in combustion cell at $35^{\circ} \mathrm{C}$

Table 3 Comparison of adsorption breakthrough time from different mass of sample

\begin{tabular}{cc}
\hline Adsorbent mass (g) & Adsorption breakthrough time (min) \\
\hline $1.0 \mathrm{~g}$ sample & 15 \\
$2.0 \mathrm{~g}$ sample & 16 \\
$3.0 \mathrm{~g}$ sample & 20 \\
$4.0 \mathrm{~g}$ sample & 26 \\
$5.0 \mathrm{~g}$ sample & 29 \\
\hline
\end{tabular}


Apparently, the $1.0 \mathrm{~g}$ of blended sample showed the lowest breakthrough time of $15 \mathrm{~min}$ followed by $2.0 \mathrm{~g}, 3.0 \mathrm{~g}, 4.0 \mathrm{~g}$, and $5.0 \mathrm{~g}$ at $16 \mathrm{~min}, 20 \mathrm{~min}$, and $29 \mathrm{~min}$ of front time, respectively, for which an increment of $\mathrm{SO}_{2}$ breakthrough time was observed. The lower adsorbent mass loading in the combustion cell causes the sample to become rapidly saturated after breakthrough. Increasing the mass load of adsorbent in the cell slightly increases the breakthrough time of $\mathrm{SO}_{2}$ adsorption. The lower mass of sample loaded in the cell generates steeper gradient of the curve, which indicates that $\mathrm{SO}_{2}$ adsorption is less effective in comparison to high mass loading. Moreover, the $5 \mathrm{~g}$ sample is considered the maximum limit, due to the limitation of the sample cup size used in the combustion cell. Hence, $5.0 \mathrm{~g}$ of blended CSRSP-AC (20:80) were found to achieve the longest $\mathrm{SO}_{2}$ adsorption breakthrough time.

\subsubsection{Effect of adsorption temperature on $\mathrm{SO}_{2}$ adsorption breakthrough time curve}

One of the important factors affecting the performance of $\mathrm{SO}_{2}$ adsorption capacity is the gas absorption temperature. Figure 4 shows the results of breakthrough time of the activated sample subjected to $\mathrm{SO}_{2}$ gas adsorption ranging from $35^{\circ} \mathrm{C}$ to $200^{\circ} \mathrm{C}$ (also see Table 4 for a summary).

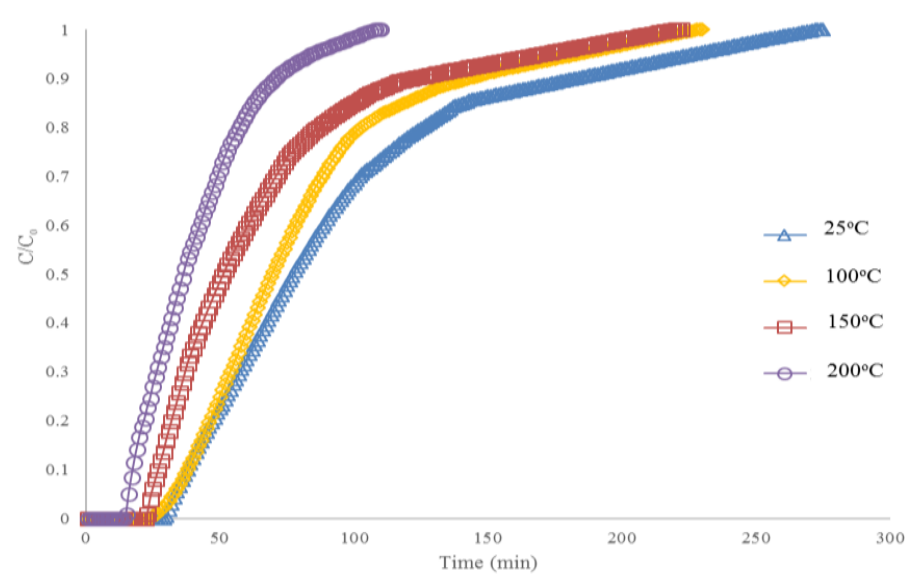

Figure $4 \mathrm{SO}_{2}$ adsorption breakthrough time curves for $5.0 \mathrm{~g}$ of blended adsorbent CSRSP-AC (20:80) at different adsorption temperatures

Table $4 \mathrm{SO}_{2}$ adsorption breakthrough time at different gas adsorption temperatures

\begin{tabular}{cc}
\hline Gas Adsorption Temperature $\left({ }^{\circ} \mathrm{C}\right)$ & Adsorption breakthrough time $(\mathrm{min})$ \\
\hline 35 & 29 \\
100 & 24 \\
150 & 22 \\
200 & 14 \\
\hline
\end{tabular}

The $\mathrm{SO}_{2}$ adsorption breakthrough time slightly decreased with the increasing temperature. At a high temperature, the kinetic energy of $\mathrm{SO}_{2}$ molecules decreased, causing the adsorption process to become exothermic (Karatepe et al., 2008). Moreover, according to Wang et al. (2016), the process of gas adsorption molecule normally undergoes exothermic reaction, in which the adsorption process decreases with an increasing temperature. As shown in Figure 4, $\mathrm{SO}_{2}$ adsorption capacity was inhibited by the increasing temperature from $100^{\circ} \mathrm{C}$ to $200^{\circ} \mathrm{C}$. Hence, the lower the adsorption temperature was, the greater the $\mathrm{SO}_{2}$ breakthrough time was recorded. Apparently, the $\mathrm{SO}_{2}$ adsorption improved at the reaction temperature below $100^{\circ} \mathrm{C}$. The longest $\mathrm{SO}_{2}$ breakthrough time of $29 \mathrm{~min}$ was observed at the temperature of $35^{\circ} \mathrm{C}$. The shortest breakthrough time was recorded at the reaction temperature of $200^{\circ} \mathrm{C}$ at $14 \mathrm{~min}$, followed by $150^{\circ} \mathrm{C}$ and $100^{\circ} \mathrm{C}$ at $22 \mathrm{~min}$ and $24 \mathrm{~min}$, respectively. The reduction of $\mathrm{SO}_{2}$ 
adsorption capacity at the same time as the increase in reaction temperature is due to the saturation of carbon surface of the activated sample. The active sites of the surface sample are blocked by sulfur and can be seen by the breakthrough profile (see Figure 4), where much steeper slopes were observed at a high temperature. At a lower temperature, the physical adsorption can be controlled, where the process undergoes catalytic oxidation in which $\mathrm{SO}_{2}$ is oxidized to $\mathrm{SO}_{3}$ by $\mathrm{O}_{2}$ and assumed as the controlling step (Wang et al., 2016). The physical adsorption at the sample surface, however, is inhibited at a high temperature, causing a small amount of $\mathrm{SO}_{2}$ being oxidized. Thus, the performance of $\mathrm{SO}_{2}$ adsorption capacity is reduced as the temperature increases. A similar observation was reported by Lee et al. (2002) with a biomass sample impregnated with $\mathrm{KOH}$, where adsorption capacity decreased as the temperature increased. This result is consistent with SEM micrograph and BET data.

\subsubsection{Effect of fly ash on $\mathrm{SO}_{2}$ adsorption breakthrough time curve}

The $\mathrm{SO}_{2}$ adsorption breakthrough time curve of blended adsorbent CSRSP-AC (20:80) with and without the presence of mixed fly ash $/ \mathrm{Ca}(\mathrm{OH})_{2}$ is shown in Figure 5 and summarized in Table 5. The results in Figure 5 indicate that the addition of fly ash/Ca(OH $)_{2}$ promotes a better performance of the $\mathrm{SO}_{2}$ adsorption breakthrough time, reaching up to $36 \mathrm{~min}$ with a lower slope increase on the curves. It can be seen that both CSRSP-AC (20:80) sample and a mixture of CSRSP-AC (20:80) with fly ash/Ca(OH $)_{2}$ demonstrated a sharp increase before subsequently achieving complete saturation after $260 \mathrm{~min}$. The coal fly ash consists of mainly silica and alumina with some metal oxides, namely $\mathrm{Fe}_{2} \mathrm{O}_{3}, \mathrm{CaO}$, and $\mathrm{MgO}$ (see Table 1). In addition, the fly ash also poses large surface area of 40 to $115 \mathrm{~m}^{2} / \mathrm{g}$. When siliceous material, such as fly ash, is mixed with $\mathrm{Ca}(\mathrm{OH})_{2}$ in hydration process, the pozzolanic reaction between alumina and silica are eluted from fly ash and calcium hydroxide. The reaction species of a complex compound was formed where the adsorbent with a high surface area and $\mathrm{SO}_{2}$ capture activity could be obtained (Jain et al., 2011). Previously, Zainudin et al. (2005) had reported that BET surface area of calcium hydroxide was $6.18 \mathrm{~m}^{2} / \mathrm{g}$. This shows that calcium hydroxide has a porous structure too. This characteristic gives advantage to both fly ash and calcium hydroxide as adsorptive materials. Therefore, the mixture of calcium hydroxide as support material on fly ash and mixed adsorbent improved the $\mathrm{SO}_{2}$ adsorption breakthrough time. Further, the presence of $\mathrm{Fe}_{2} \mathrm{O}_{3}$ in the fly ash also catalyzed the oxidative reaction of $\mathrm{SO}_{2}$ to $\mathrm{SO}_{3}$ (Belo et al., 2014). The $\mathrm{SO}_{3}$ is easily captured by $\mathrm{CaO}$ and $\mathrm{MgO}$ in the fly ash forming sulfates, which leads to a higher removal of $\mathrm{SO}_{2}$ from the system, as indicated by longer breakthrough time (Wang et al., 2012).

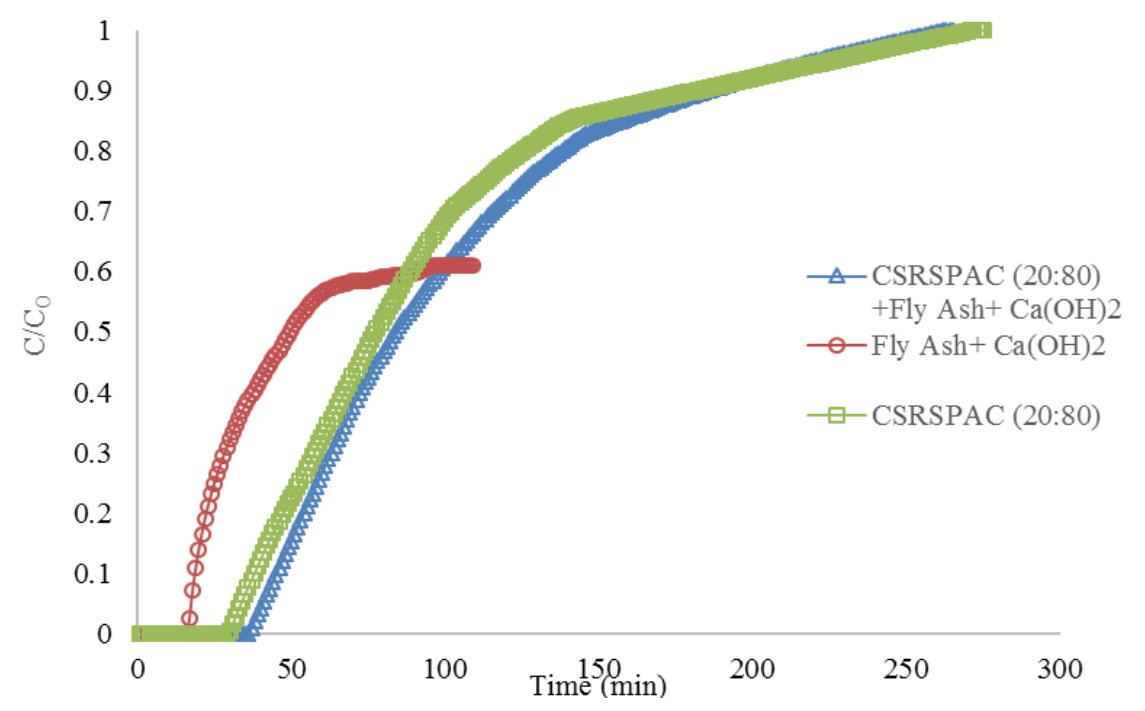

Figure $5 \mathrm{SO}_{2}$ adsorption breakthrough time for $5.0 \mathrm{~g}$ of blended CSRSP-AC (20:80) at $35^{\circ} \mathrm{C}$ adsorption temperature with and without fly ash/ $\mathrm{Ca}(\mathrm{OH})_{2}$ 
Table 5 Comparison of adsorption breakthrough time of CSRSP-AC (80:20) with and without fly ash $/ \mathrm{Ca}(\mathrm{OH})_{2}$ as catalyst

\begin{tabular}{lc}
\hline \multicolumn{1}{c}{ Sample } & Time (min) \\
\hline CSRSP-AC $(20: 80)$ at $25^{\circ} \mathrm{C}$ & 29 \\
Fly ash $+\mathrm{Ca}(\mathrm{OH})_{2}$ at $25^{\circ} \mathrm{C}$ & 16 \\
CSRSP-AC $(20: 80)+\mathrm{Fly}$ ash $+\mathrm{Ca}(\mathrm{OH})_{2}$ at $25^{\circ} \mathrm{C}$ & 36 \\
\hline
\end{tabular}

\subsection{Comparison of SEM Image}

Figure 6 compares the surface morphology of the samples before and after $\mathrm{SO}_{2}$ adsorption based on the effect of temperature and catalyst. Figure 6a corresponds to CSRSP-AC with a ratio of 20:80 (CS:RSP) before the $\mathrm{SO}_{2}$ adsorption process. The micrograph shows the presence of pores on the surface of the sample. Figure $6 \mathrm{~b}$ shows the micrograph of CSRSP-AC with the ratio of 20:80 (CS:RSP) after $\mathrm{SO}_{2}$ adsorption at $35^{\circ} \mathrm{C}$. Apparently, the porous surface of the adsorbent was less visible and clogged up after the reaction with $\mathrm{SO}_{2}$. These observations are almost similar to SEM micrograph reported by Zainudin et al. (2005) before and after the $\mathrm{SO}_{2}$ capture. At $100^{\circ} \mathrm{C}$, the surface of the sorbent (see Figure $6 \mathrm{c}$ ) is thick, and the pores are no longer visible because they are covered by a layer of product (sulfate) after the adsorption of $\mathrm{SO}_{2}$. This means that the $\mathrm{SO}_{2}$ contaminants are fully adsorbed by the sorbent after the $\mathrm{SO}_{2}$ adsorption process. The pore structures get blocked as the temperature increases and this causes a decrease in the breakthrough time of $\mathrm{SO}_{2}$ gas adsorption. Figure 6d shows the surface morphology of CSRSP-AC (20:80), coated with fly ash/Ca(OH) $)_{2}$ after the $\mathrm{SO}_{2}$ adsorption. The sample surface was clogged, and some of the ash spherical structure was deposited on the sample surface. These images are also consistent with the breakthrough time of $\mathrm{SO}_{2}$ gas adsorption in which the extra fly ash improves the $\mathrm{SO}_{2}$ adsorption performance. Figure 6e illustrates the SEM micrograph of fly ash/Ca(OH) 2 after $\mathrm{SO}_{2}$ adsorption. The surface was covered by lumps, and some agglomerates were clustered on the plate, illustrating that the $\mathrm{SO}_{2}$ was adsorbed thoroughly by fly ash/Ca(OH) 2 .
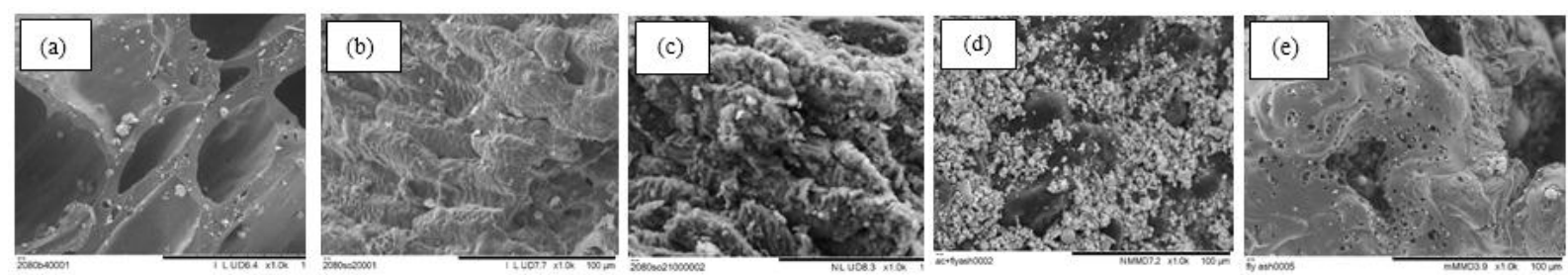

Figure 6 SEM image (1000x) of: (a) CSRSP-AC (20:80) before adsorption; (b) CSRSP-AC (20:80) after $\mathrm{SO}_{2}$ adsorption at $35^{\circ} \mathrm{C}$; (c) CSRSP-AC (20:80) after $\mathrm{SO}_{2}$ adsorption at $100^{\circ} \mathrm{C}$; (d) CSRSP-AC (20:80) coated with fly ash and $\mathrm{Ca}(\mathrm{OH})_{2}$ after $\mathrm{SO}_{2}$ adsorption; (e) fly ash and $\mathrm{Ca}(\mathrm{OH})_{2}$ after adsorption of $\mathrm{SO}_{2}$

\subsection{The BET Surface Area}

Table 6 shows the BET surface area of the blended CSRSP-AC with a ratio of 20:80 (CS:RSP) before and after $\mathrm{SO}_{2}$ adsorption at the temperatures of $35^{\circ} \mathrm{C}$ and $100^{\circ} \mathrm{C}$. The blended sample before adsorption exhibits a higher BET surface area of $332.83 \mathrm{~m}^{2} / \mathrm{g}$ with a total pore volume of $0.14702 \mathrm{~cm}^{3} / \mathrm{g}$ and a pore diameter of 2.8501 . A high BET value was detected because the sample was not subjected to $\mathrm{SO}_{2}$ adsorption. This conforms to the SEM image (Figure 6a), which displays well-developed pores drilling over the surface of the adsorbent. However, the BET value dropped after the adsorption of $\mathrm{SO}_{2}$ at $35^{\circ} \mathrm{C}$ with $295.63 \mathrm{~m}^{2} / \mathrm{g}$ of BET surface area, 0.12853 total pore volume, and $2.7143 \mathrm{~nm}$ of pore diameter. This indicates that the blocking of some pores and the adsorption of $\mathrm{SO}_{2}$ on the surface of the adsorbent were successful since the 
BET value declined. According to Liu and Adanur (2014), the adsorption capacity of gases are inversely proportional to pore size and pore volume where adsorbates with smaller pores are better able to adsorb the gas contaminant. It is noticeable that increasing the $\mathrm{SO}_{2}$ absorption temperature from $35^{\circ} \mathrm{C}$ to $100^{\circ} \mathrm{C}$ will slightly increase the BET surface area of the adsorbent. In addition, the total pore volume $\left(\mathrm{V}_{\text {tot }}\right)$ also increases in the same manner as the BET surface area with a value of $0.13178 \mathrm{~cm}^{3} / \mathrm{g}$. It seems that the adsorbent becomes slightly porous after the $\mathrm{SO}_{2}$ adsorption, indicating that less pore blockage has occurred. However, the difference between the BET surface area and the total pore volume between the blended samples after $\mathrm{SO}_{2}$ treatment at $35^{\circ} \mathrm{C}$ and $100^{\circ} \mathrm{C}$ are considered small. To verify further, these selected adsorbents were subjected to the SEM analysis to observe the surface morphology after $35^{\circ} \mathrm{C}$ and $100^{\circ} \mathrm{C}$ $\mathrm{SO}_{2}$ adsorption treatment. The SEM images of both samples (see Figure 6) illustrated the thickening of the adsorbent wall with the appearance of lumps (i.e., sulfated products) as a result of $\mathrm{SO}_{2}$ absorption reaction.

Table 6 Pore characteristics of CSRSP-AC adsorbent (20:80; CS:RSP) before and after $\mathrm{SO}_{2}$ gas adsorption at different adsorption temperatures

\begin{tabular}{lccc}
\hline \multicolumn{1}{c}{ Sample } & $\mathrm{S}_{\mathrm{BET}}\left(\mathrm{m}^{2} / \mathrm{g}\right)$ & $\mathrm{V}_{\text {Tot }}\left(\mathrm{cm}^{3} / \mathrm{g}\right)$ & $\mathrm{D}_{\mathrm{p}}(\mathrm{nm})$ \\
\hline CSRSP-AC before adsorption & 332.83 & 0.14702 & 2.8501 \\
CSRSP-AC after $\mathrm{SO}_{2}$ adsorption at $35^{\circ} \mathrm{C}$ & 295.63 & 0.12853 & 2.7143 \\
CSRSP-AC after $\mathrm{SO}_{2}$ adsorption at $100^{\circ} \mathrm{C}$ & 296.52 & 0.13178 & 3.2205 \\
\hline
\end{tabular}

$\mathrm{S}_{\mathrm{BET}}$ : BET surface area; $\mathrm{V}_{\text {Tot }}$ : Total pore volume; $\mathrm{D}_{\mathrm{p}}$ : Average pore diameter

\section{CONCLUSION}

Adsorption capacity of $\mathrm{SO}_{2}$ on biomass activated carbon (CS-AC, RSP-AC) and their blends (CSRSP-AC) were tested and monitored by an evolved gas analyzer. The single microporous RSP-AC exhibits the longest $\mathrm{SO}_{2}$ breakthrough time of $23 \mathrm{~min}$ in comparison to the single CSAC at $14 \mathrm{~min}$. Among the blended samples, the 20:80 (CS:RSP-AC) was found to have the longest $\mathrm{SO}_{2}$ adsorption breakthrough time $\left(\mathrm{C} / \mathrm{C}_{0}\right)$ of $15 \mathrm{~min}$. A high amount of RSP in the blended sample promotes a longer $\mathrm{SO}_{2}$ breakthrough time. The relationship between the $\mathrm{SO}_{2}$ breakthrough time and the adsorption temperature was analyzed, and the highest breakthrough time recorded was at $35^{\circ} \mathrm{C}$ with $29 \mathrm{~min}$ of adsorption breakthrough time. Increasing the adsorption temperature slightly reduces the $\mathrm{SO}_{2}$ adsorption capacity. The addition of fly ash $/ \mathrm{Ca}(\mathrm{OH})_{2}$ catalyst that contains $\mathrm{CaO}$ and $\mathrm{MgO}$ with activated carbon increases the performance of adsorption capacity, where the breakthrough time was increased to $36 \mathrm{~min}$. The SEM image showed that the porosity of adsorbent was reduced through the surface coverage by the reaction of the product, which means that the $\mathrm{SO}_{2}$ adsorption activity has been successful.

\section{ACKNOWLEDGEMENT}

This research project was funded by the Ministry of Higher Education, Malaysia (MOHE) under the Fundamental Research Grant Scheme (FRGS), Grant No: FRGS/1/2017/TK10/UITM/02/11. The authors also acknowledge Universiti Teknologi MARA for providing facilities during the research work.

\section{REFERENCES}

Amin, Y.M., Khandaker, M.U., Shyen, A.K.S., Mahat, R.H., Nor, R.M., Bradley, D.A., 2013. Radionuclide Emissions from a Coal-fired Power Plant. Applied Radiation and Isotopes, Volume 80, pp. 109-116 
Bai, B.C., Lee, C.W., Lee, Y.S., Im, J.S., 2016. Metal Impregnate on Activated Carbon Fiber for $\mathrm{SO}_{2}$ Gas Removal: Assessment of Pore Structure, $\mathrm{Cu}$ Supporter, Breakthrough, and Bed Utilization. Colloids and Surfaces A: Physicochemical and Engineering Aspects, Volume 509, pp. 73-79

Belo, L.P., Elliott, L.K., Stanger, R.J., Spörl, R., Shah, K.V., Maier, J., Wall, T.F., 2014. HighTemperature Conversion of $\mathrm{SO}_{2}$ to $\mathrm{SO}_{3}$ : Homogeneous Experiments and Catalytic Effect of Fly Ash from Air and Oxy-fuel Firing. Energy \& Fuels, Volume 28(11), pp. 7243-7251

Dahlan, I., Mei, G.M., Kamaruddin, A.H., Mohamed, A.R., Lee, K.T., 2008. Removal of $\mathrm{SO}_{2}$ and NO Over Rice Husk Ash (RHA)/CaO-Supported Metal Oxides. Journal of Engineering Science and Technology, Volume 3(2), pp. 109-116

Idris, S.S., Rahman, N.A., Ismail, K., 2012. Combustion Characteristics of Malaysian Oil Palm Biomass, Sub-bituminous Coal and Their Respective Blends via Thermogravimetric Analysis (TGA). Bioresource Technology, Volume 123, pp. 581-591

Ismail, K.N., Hussin, K., Idris, M.S., 2007. Physical, Chemical and Mineralogical Properties of Fly Ash. Journal of Nuclear and Related Technology, Volume 4, pp. 47-51

Izquierdo, M.T., Rubio, B., 2008. Carbon-enriched Coal Fly Ash as a Precursor of Activated Carbons for $\mathrm{SO}_{2}$ Removal. Journal of Hazardous Materials, Volume 155(1-2), pp. 199205

Jain, D., Khatri, C., Rani, A., 2011. Synthesis and Characterization of Novel Solid Base Catalyst from Fly Ash. Fuel, Volume 90(6), pp. 2083-2088

Karatepe, N., Orbak, İ., Yavuz, R., Özyuğuran, A., 2008. Sulfur Dioxide Adsorption by Activated Carbons Having Different Textural and Chemical Properties. Fuel, Volume 87(15-16), pp. 3207-3215

Lee, Y.W., Park, J.W., Choung, J.H., Choi, D.K., 2002. Adsorption Characteristics of $\mathrm{SO}_{2}$ on Activated Carbon Prepared from Coconut Shell with Potassium Hydroxide Activation. Environmental Science \& Technology, Volume 36(5), pp. 1086-1092

Leong, S.K., Lam, S.S., Ani, F.N., Ng, J.H., Chong, C.T., 2016. Production of Pyrolyzed Oil from Crude Glycerol using a Microwave Heating Technique. International Journal of Technology, Volume 7(2), pp. 323-331

Liu, W., Adanur, S., 2014. Desulfurization Properties of Activated Carbon Fibers. Journal of Engineered Fibers \& Fabrics, Volume 9(2), pp. 70-75

Rubio, B., Izquierdo, M.T., 2010. Coal Fly Ash Based Carbons for $\mathrm{SO}_{2}$ Removal from Flue Gases. Waste Management, Volume 30(7), pp. 1341-1347

Shao, J., Zhang, J., Zhang, X., Feng, Y., Zhang, H., Zhang, S., Chen, H., 2018. Enhance $\mathrm{SO}_{2}$ Adsorption Performance of Biochar Modified by $\mathrm{CO}_{2}$ Activation and Amine Impregnation. Fuel, Volume 224, pp. 138-146

Shukor, N.S.A., Ismail, K., Raja Deris, R.R., Alias, A.B., Ishak, M.A.M., 2017. Production and Characterisation of Single and Mixed Activated Carbons from Coconut Shell and Rubber Seed Pericarp using Microwave-induced Chemical Activating Agent. Materials Science Forum, Volume 889, pp. 209-214

Sumathi, S., Bhatia, S., Lee, K.T., Mohamed, A.R., 2010. Selection of Best Impregnated Palm Shell Activated Carbon (PSAC) for Simultaneous Removal of $\mathrm{SO}_{2}$ and $\mathrm{NO}_{\mathrm{x}}$. Journal of Hazardous Materials, Volume 176(1-3), pp. 1093-1096

Sun, Y., Yang, G., Zhang, L., 2018. Hybrid Adsorbent Prepared from Renewable Lignin and Waste Egg Shell for $\mathrm{SO}_{2}$ Removal: Characterization and Process Optimization. Ecological Engineering, Volume 115, pp. 139-148

Uçar, S., Erdem, M., Tay, T., Karagöz, S., 2009. Preparation and Characterization of Activated Carbon Produced from Pomegranate Seeds by $\mathrm{ZnCl}_{2}$ Activation. Applied Surface Science, Volume 255(21), pp. 8890-8896 
Wang, J., Meng, X., Chen, J., Yu, Y., Miao, J., Yu, W., Xie, Z., 2016. Desulphurization Performance and Mechanism Study by In-situ DRIFTS of Activated Coke Modified by Oxidization. Industrial \& Engineering Chemistry Research, Volume 55(13), pp. 37903796

Wang, S., 2008. Application of Solid Ash Based Catalysts in Heterogeneous Catalysis. Environmental Science \& Technology, Volume 42(19), pp. 7055-7063

Wang, S., Wu, H., 2006. Environmental-benign Utilisation of Fly Ash as Low-cost Adsorbents. Journal of Hazardous Materials, Volume 136(3), pp. 482-501

Wang, Z., Huan, Q., Qi, C., Zhang, L., Cui, L., Xu, X., Ma, C., 2012. Study on the Removal of Coal Smoke $\mathrm{SO}_{3}$ with $\mathrm{CaO}$. Energy Procedia, Volume 14, pp. 1911-1917

Yang, A.L.C., Ani, F.N., 2016. Controlled Microwave-induced Pyrolysis of Waste Rubber Tires. International Journal of Technology, Volume 7(2), pp. 314-322

Yao, Z.T., Ji, X.S., Sarker, P.K., Tang, J.H., Ge, L.Q., Xia, M.S., Xi, Y.Q., 2015. A Comprehensive Review on the Applications of Coal Fly Ash. Earth-Science Reviews, Volume 141, pp. 105-121

Zainudin, N.F., Lee, K.T., Kamaruddin, A.H., Bhatia, S., Mohamed, A.R., 2005. Study of Adsorbent Prepared from Oil Palm Ash (OPA) for Flue Gas Desulfurization. Separation and Purification Technology, Volume 45(1), pp. 50-60 